\title{
Root growth and proton efflux rates of rice seedlings in a greenhouse environment
}

\author{
Marcel Giovanni Costa França ${ }^{1,3}$, Roberto Oscar Pereyra Rossiello², Flávia Toledo Ramos ${ }^{2}$ and \\ Everaldo Zonta ${ }^{2}$
}

Received: March 24, 2004. Accepted: June 15, 2005.

\begin{abstract}
RESUMO - (Taxas de crescimento de raízes e de efluxo de prótons em plântulas de arroz em ambiente de casa de vegetação). Foram avaliados o crescimento e o efluxo de prótons $\left(\mathrm{E}_{\mathrm{H}}^{+}\right)$em raízes de plântulas de arroz (Oryza sativa cv. IAC 47) cultivadas sob as condições de luz de uma casa de vegetação. Quinze dias após a emergência, plântulas foram transplantadas para potes contendo 3,7 L de uma solução nutritiva com $1,43 \mathrm{mmol} \mathrm{N}-\mathrm{NH}_{4}^{+} \mathrm{L}^{-1}$ como fonte exclusiva de nitrogênio, visando induzir quatro ciclos seqüenciais de acidificação da solução, a partir de um valor de $\mathrm{pH}$ inicial de 5,3. Os efluxos médios de prótons foram calculados com base em períodos de crescimento radicular de $48 \mathrm{~h}$ (de $0 \mathrm{a} 192 \mathrm{~h}$ ). As estimativas de $\mathrm{E}_{\mathrm{H}}{ }^{+}$foram obtidas a partir dos valores calculados para as Taxas de Crescimento Relativo (TCR), expressas com base na área radicular (AR), ou massa fresca radicular (MF), e das pendentes da regressão linear da quantidade de prótons livres na solução $\left(\mathrm{U}_{\mathrm{H}}{ }^{+}\right)$sobre $\mathrm{MF}$ ou $\mathrm{AR}$. Os gradientes de acidificação $\left(\Delta \mathrm{U}_{\mathrm{H}}{ }^{+} / \Delta \mathrm{MF}\right)$ foram melhor associados quando relacionados com MF do que com AR. As taxas de crescimento das raízes foram afetadas por flutuações de radiação fotossintética e temperatura dentro da casa de vegetação e não se relacionaram claramente com os valores de $\mathrm{E}_{\mathrm{H}}{ }^{+}$. Todavia, foi concluído que quando existe uma relação linear entre $\mathrm{U}_{\mathrm{H}}{ }^{+}$e $\mathrm{MF}$, as avaliações de $\mathrm{E}_{\mathrm{H}}{ }^{+}$expressas por unidades de $\mathrm{MF}$, podem ser mais confiáveis do que aquelas expressas por unidades de AR.
\end{abstract}

Palavras-chave: área radicular, massa fresca radicular, taxa de crescimento relativo, gradiente de acidificação

\begin{abstract}
Root growth and proton efflux rates of rice seedlings in a greenhouse environment). Growth patterns and mean proton efflux rates $\left(\mathrm{E}_{\mathrm{H}}^{+}\right)$in roots of rice seedlings (Oryza sativa cv. IAC 47) grown under light conditions in a greenhouse environment were

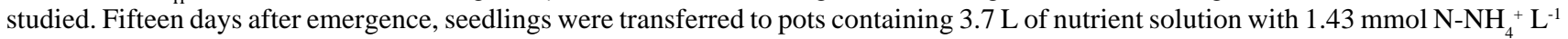
as the sole source of nitrogen, to induce four sequential cycles of solution acidification, starting with a pH value of 5.3. Mean proton effluxes were computed based on growth periods of $48 \mathrm{~h}$ (from 0 to $192 \mathrm{~h}$ ). $\mathrm{E}_{\mathrm{H}}^{+}$values were estimated from values of relative root growth rates (RGR), expressed as root area (RA) or fresh mass (FM), and the linear coefficient of the regression of total free protons in nutrient solution $\left(\mathrm{U}_{\mathrm{H}}^{+}\right)$on RA or FM. Total free protons in the solution and the acidification gradients $\left(\Delta \mathrm{U}_{\mathrm{H}}{ }^{+} / \Delta \mathrm{MF}\right)$ were better related to FM than to RA. Root growth rates were affected by photosynthetic irradiance and temperature fluctuations in the greenhouse, and were not clearly related to $\mathrm{E}_{\mathrm{H}}^{+}$values. However, it was concluded that when a linear relation between $\mathrm{U}_{\mathrm{H}}{ }^{+}$and fresh root mass is found, $\mathrm{E}_{\mathrm{H}}{ }^{+}$ estimates expressed by FM may be more reliable than when expressed by RA units.
\end{abstract}

Key words: root area, fresh root mass, relative growth rate, acidification gradient

\section{Introduction}

Active proton $\left(\mathrm{H}^{+}\right)$efflux linked to plasma membrane $\mathrm{H}^{+}$-ATPase activity plays a central role in plant cell physiology (Michelet \& Boutry 1995), taking part in metabolism and growth, through processes such as cytoplasmatic $\mathrm{pH}$ regulation, maintenance of turgor, cell wall relaxation and polarity rise in growing cells (Serrano 1989; Stiles et al. 2003; Mantelin \& Touraine
2004). From a nutritional perspective, since proton efflux is an electrogenic process (Berbara et al. 1995; Lew 1996; 1998), it represents the most important mineral nutrition mechanism in plants (Fernandes \& Rossiello 1995). It has been proved that if an excess of positively charged ions is transported through the plasma membrane of root cortical cells, an equivalent amount of positive charge should be transported to the apoplastic domain, to avoid either intracellular

\footnotetext{
1 Instituto de Ciências Biológicas, Departamento de Botânica, Universidade Federal de Minas Gerais, Av. Antônio Carlos, 6627, Pampulha, CEP 31270-901, Belo Horizonte, MG, Brasil

2 Universidade Federal Rural do Rio de Janeiro, Instituto de Agronomia, Departamento de Solos, Km 7 - Br 465, CEP 23850-000, Seropédica, RJ, Brasil

3 Corresponding Author: marcel@icb.ufmg.br
} 
depolarization or extreme $\mathrm{pH}$ fluctuations in the citosol (Raven \& Smith 1976; Serrano 1989; Shabala \& Newman 2000). As a consequence, absorption of positively charged ions, especially of those of high metabolic demand, causes an acidification of the rhizosphere, as a result of the net $\mathrm{H}^{+}$efflux associated with nutrient uptake (Fernandes et al. 1981; Smart \& Bloom 1998). This acidification modifies the physiochemical properties of the root environment (Luisi et al. 1983), which in turn affects biological activities, nutrient availability and root growth rates (Fernandes \& Rossiello 1995; França et al. 1999; Mantelin \& Touraine 2004).

In a changing environment, under natural light conditions, plant growth processes will change, depending on metabolic energy availability. Under favourable growth conditions, one can also expect changes in root $\mathrm{H}^{+}$efflux rates, associated with events related to cellular growth and ion transport through the plasma membrane. In the present study our hypothesis was that during short periods of time, in the exponential growth phase of rice seedlings, it is possible to identify functional relationships between proton efflux rates and some root traits. To test this, rice (Oryza sativa L.) seedlings were grown in nutrient solution, with $\mathrm{N}-\mathrm{NH}_{4}^{+}$ as sole source of $\mathrm{N}$, to induce sequential cycles of acidification in the nutrient solution. The extent of the acidification was compared to variations in fresh mass and surface area of roots, in order to verify which one offers a better base for the determination of proton efflux rates.

\section{Material and methods}

Growth conditions - The experiment was carried out in a greenhouse under natural light conditions. During the experimental period, the relative humidity $(\mathrm{RH})$, air temperatures and Photosynthetically Active Radiation (PAR) were monitored daily. Relative humidity and air temperatures were registered with a thermo-hygrograph (BENDIX, Friez Instrument Division, model 594). RH varied from $50-60 \%$ (day) to $93-100 \%$ (night). Air temperatures are shown in Fig.1A. PAR measurements were taken three times per day, in the form of Photosynthetic Photon Flux Density, with a quantum sensor (LI-190 SB) coupled to a portable radiometer (LI-COR 185, Li-Cor, Inc.) (Fig. 1B). Rice seeds of an upland cultivar (IAC 47) were surface sterilized with $\mathrm{NaOCl} 0.5 \%$ for 45 minutes, rinsed with deionized water (30 minutes) and put to germinate in a substrate composed of a mixture of vermiculite and washed sand (1:1). After emergence, the seedlings received a nutrient solution specific for rice growth (Furlani \& Furlani 1988) at half of its original concentration. Nitrogen $\left(1.43 \mathrm{mmol} \mathrm{N} \mathrm{L}^{-1}\right)$ was supplied exclusively in $\mathrm{N}-\mathrm{NH}_{4}{ }^{+}$form, as $\left(\mathrm{NH}_{4}\right)_{2} \mathrm{SO}_{4}$. Experimental procedure - Fifteen-day-old seedlings were transferred to plastic pots containing $3.7 \mathrm{~L}$ of nutrient solution at full strength. The solution $\mathrm{pH}$ was adjusted to a basal value of 5.3. The treatments were defined according to the time that seedlings stayed in the test solution: 0, 48, 96, 144 and 192 hours. Every 48 hours, which corresponds to one root growth cycle out of four, the $\mathrm{pH}$ was measured and the acidity balanced by adding the proper amount of base $(\mathrm{NaOH}$ $0.1 \mathrm{~N}$ ) in order to return to the basal $\mathrm{pH}$ value. At the end of each $48 \mathrm{~h}$ growth period, three pots were removed to measure the following parameters: total
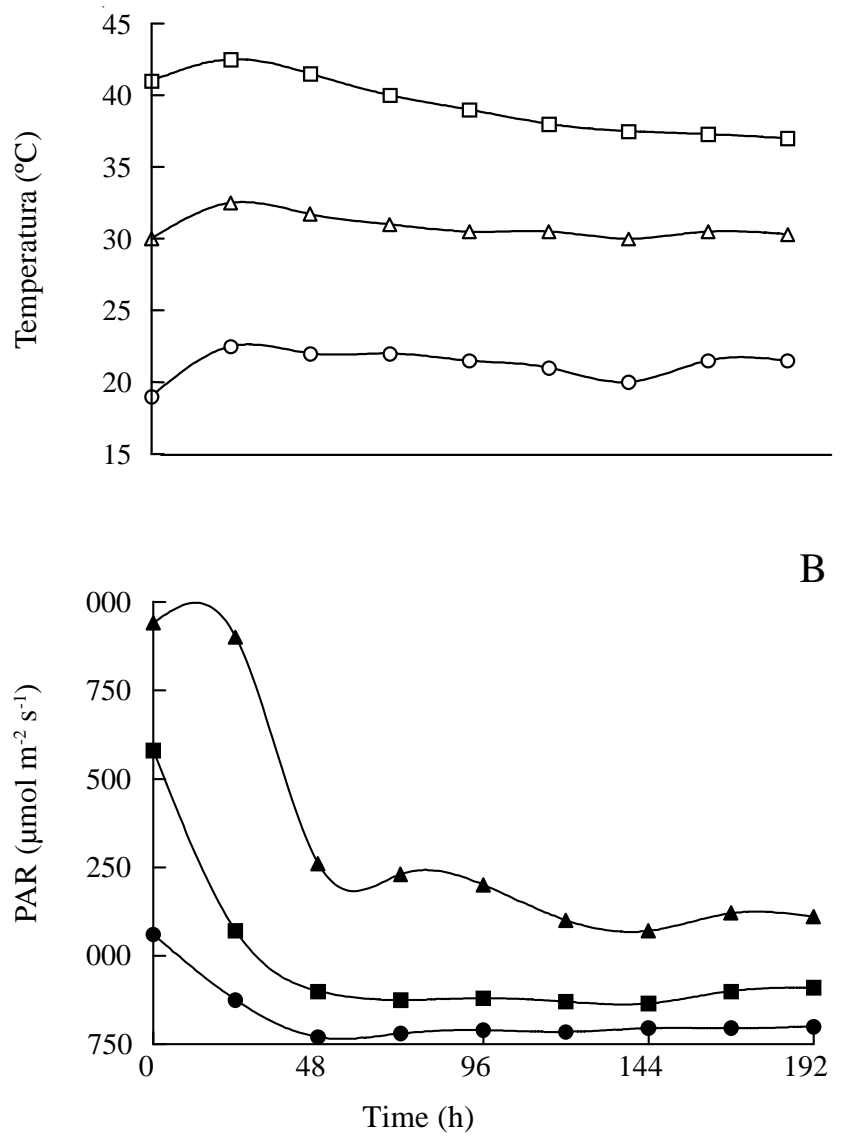

Figure 1. (A) Maximum ( $\square$ ), mean $(\triangle)$ and minimum $(\bigcirc)$ air temperatures (A), and photon-flux density of Photosynthetically Active Radiation (PAR) (B), under greenhouse conditions during the experimental period of rice seedling cultivation. 9:00 h; A 12:00 h; 15:00 h. 
root area $\left(\mathrm{RA}, \mathrm{cm}^{2}\right)$, using an electronic area meter (LI-COR 3000) (Rossiello et al. 1995), fresh and dry root weight (FM or DM, g), and maximum seminal root length (SRL, cm). Fresh roots were dried at $70{ }^{\circ} \mathrm{C}$ in a forced air circulation oven until constant weight was reached. Except for SLR, all the values were expressed on a 4 plants pot ${ }^{-1}$ basis.

Calculation of $\mathrm{H}^{+}$efflux - root area ${ }^{-1}-$ The instantaneous net $\mathrm{H}^{+}$efflux of a root system contained in a known volume can be approximated by the following equation:

$$
\mathrm{E}_{\mathrm{H}^{+}}=\frac{1}{\mathrm{RA}} \bullet \frac{\mathrm{dU}_{\mathrm{H}^{+}}}{\mathrm{dT}}
$$

where: $\mathrm{E}_{\mathrm{H}}^{+}=$efflux $\left(\mu \mathrm{mol} \mathrm{cm} \mathrm{cm}^{-2} \mathrm{~h}^{-1}\right) ; \mathrm{U}_{\mathrm{H}}{ }^{+}=$total free proton in nutrient solution $\left(\mu \mathrm{mol} \mathrm{H}^{+}\right.$pot $\left.^{-1}\right) ; \mathrm{RA}=$ root area $\left(\mathrm{cm}^{2}\right.$ pot $\left.^{-1}\right)$ and $\mathrm{T}=$ time (hours). Equation (I) involves a lot of uncertainty, due to (1) axial variation of $\mathrm{H}^{+}$influx-efflux in the root apex (Miller et al. 1986; Berbara et al. 1995; Plassard et al. 1999), (2) technical difficulties related to $\mathrm{H}^{+}$activity determination in the root surface (Ryan et al. 1992; Plassard et al. 1999) and (3) the inaccuracy of root area quantification (Rossiello et al. 1995). For this last reason, root $\mathrm{E}_{\mathrm{H}}{ }^{+}$is frequently better expressed per FM or DM than per RA units. However, an analytical solution for equation I is:

$$
\overline{\mathrm{E}}_{\mathrm{H}^{+}}=\frac{\mathrm{LnRA}_{2}-\mathrm{LnRA}_{1}}{\mathrm{~T}_{2}-\mathrm{T}_{1}} \cdot \frac{\mathrm{U}_{\mathrm{H}_{2}^{+}}-\mathrm{U}_{\mathrm{H}_{1}^{+}}}{\mathrm{RA}_{2}-\mathrm{RA}_{1}}
$$

This equation expresses the integration of equation (I) for a given time interval $\left(\mathrm{T}_{2}-\mathrm{T}_{1}\right)$, since a linear relationship can exist between $\mathrm{U}_{\mathrm{H}}{ }^{+}$and RA. The first term on the right side of equation (II) represents the Relative Root Area Growth Rate $\left(\mathrm{RGR}_{\mathrm{RA}}\right.$, $\left.\mathrm{cm}^{2} \mathrm{~cm}^{-2} \mathrm{~h}^{-1}\right)$. The second $\left(\Delta \mathrm{U}_{\mathrm{H}}{ }^{+} / \Delta_{\mathrm{RA}}, \mu \mathrm{mol} \mathrm{H} \mathrm{H}^{+} \mathrm{cm}^{-2}\right)$ represent the slope coefficient of a regression between $\mathrm{U}_{\mathrm{H}}{ }^{+}$and RA. The $\mathrm{U}_{\mathrm{H}}{ }^{+}$value was calculated as the product of the $\mathrm{H}^{+}$concentration $\left(\mathrm{mol} \mathrm{L}^{-1}\right.$, from measured $\mathrm{pH}$ ) and the volume of the solution. Potentiometric $\mathrm{pH}$ measurements were made directly in the solution, by taking out the roots and mixing for $60 \mathrm{~s}$ with a glass stick. The same equation (II) was used to estimate $\mathrm{E}_{\mathrm{H}}^{+}$on a fresh root mass basis, by substituting RA by FM in the regression analysis.

Statistical analyses - The experiment was arranged in an entirely randomized design, with five treatments and three replicates. Experimental data were normally distributed (Lilliefors test) with homoscedastic residual variance (Cochran test). Significant mean differences were determined using a Tukey test $(P \leq 0.05)$. All statistical analyses were performed using Systat v. 8.0.

\section{Results and discussion}

Environmental conditions - The thermal characteristics of the glass cover led to increased heat inside the greenhouse during daytime. During the first 24 hours maximum air temperatures were around $40-42^{\circ} \mathrm{C}$ while minimum temperatures were around $20-22{ }^{\circ} \mathrm{C}$ (Fig. 1A). Photon-flux density (PAR), measured at canopy level, at midday, was about $1900 \mu \mathrm{mol} \mathrm{m} \mathrm{m}^{-2} \mathrm{~s}^{-1}$ (Fig. 1B). Forty-eight hours after the beginning of the experiment cloudy skies were prevalent; this resulted in decreased PAR, especially at midday. That also contributed to keeping mean air temperatures well over $30{ }^{\circ} \mathrm{C}$.

Root growth - Tab. 1 shows the variation of RA, FM, DM and SRL values during the 192 hours of the experiment. For all measurements there was a progressive time-dependent increase, which was an expression of root growth, which is considered, at the cellular level, as an irreversible expansion in volume (Hsiao et al. 1976). In fact, the closest substitute of root volume, the fresh mass (FM), is a more sensitive indicator of root growth progression than are RA or SL. The four growth periods could not be clearly separeted by DM (compare statistical significance levels, Tab.1). Figure 2 shows RGR values based on RA or FM. RGR $_{\mathrm{RA}}$ varied among the four growth periods (Fig. 2A). The decrease observed between 96 and 144 hours (a reduction of $66 \%$ when compared with the precedent period) was significant $(P \leq 0.05)$ and it cannot be clearly explained, but it was followed by a recovery of the RGR in the subsequent period. Mean $\mathrm{RGR}_{\mathrm{FM}}$ declined in a continuous way during the experiment, and the rate in the $144-192 \mathrm{~h}$ period was

Table 1. Variation of root area (RA), fresh mass (FM), dry mass (DM) and seminal root maximum length (SRL) of rice seedlings in

\begin{tabular}{|c|c|c|c|c|c|}
\hline \multirow{2}{*}{$\begin{array}{l}\text { Time } \\
\text { (h) }\end{array}$} & \multirow{2}{*}{$\begin{array}{c}\mathrm{RA} \\
\left(\mathrm{cm}^{2} \text { pot }^{-1}\right)\end{array}$} & FM & & $\mathrm{DM}$ & \multirow{2}{*}{$\begin{array}{l}\text { SRL } \\
(\mathrm{cm})\end{array}$} \\
\hline & & \multicolumn{3}{|c|}{$\left(\mathrm{g} \mathrm{pot}^{-1}\right)$} & \\
\hline 0 & $8.70 \mathrm{~d}^{(1)}$ & 0.095 & $\mathrm{e}$ & $0.017 \mathrm{~d}$ & $8.68 \mathrm{~d}$ \\
\hline 48 & $19.92 \mathrm{~d}$ & 0.185 & $\mathrm{~d}$ & $0.029 \mathrm{~cd}$ & $10.04 \mathrm{~cd}$ \\
\hline 96 & $48.23 \mathrm{c}$ & 0.303 & $\mathrm{c}$ & $0.040 \mathrm{bc}$ & $11.34 \mathrm{c}$ \\
\hline 144 & $64.70 \mathrm{~b}$ & 0.474 & $\mathrm{~b}$ & $0.053 \mathrm{ab}$ & $13.40 \mathrm{~b}$ \\
\hline 192 & $122.40 \mathrm{a}$ & 0.686 & $\mathrm{a}$ & $0.067 \mathrm{a}$ & $18.18 \mathrm{a}$ \\
\hline
\end{tabular}
relation to time spent in nutrient solution.

(1) Values are means of three replicates. Within a column, means followed by the same letter did not differ significantly by Tukey's test $(P \leq 0.05)$ 
44\% lower than the value observed in the initial growth period ( $0-48$ h, Fig. 2B). Such variations in RGR, around a constant medium value, typical of the exponential growth phase, should be attributed to environmental fluctuations. High temperature and PAR levels during the initial period could have stimulated greater absorption of $\mathrm{NH}_{4}^{+}$, but also could have accelerated respiration rates, mainly in the shoot (Fernandes \& Rossiello 1995). As a consequence, less carbohydrate would be exported to the roots, where, in addition, the $\mathrm{NH}_{4}^{+}$assimilation process consumes carbon skeletons that otherwise could be used in cellular growth processes (Silva et al. 1987).

$\mathrm{H}^{+}$efflux - Tab. 2 shows the $\mathrm{pH}$ values, measured every $48 \mathrm{~h}$, at the end of each one of the four cycles of solution acidification. In the first 96 hours, the level of acidification per period was similar, suggesting that the

A
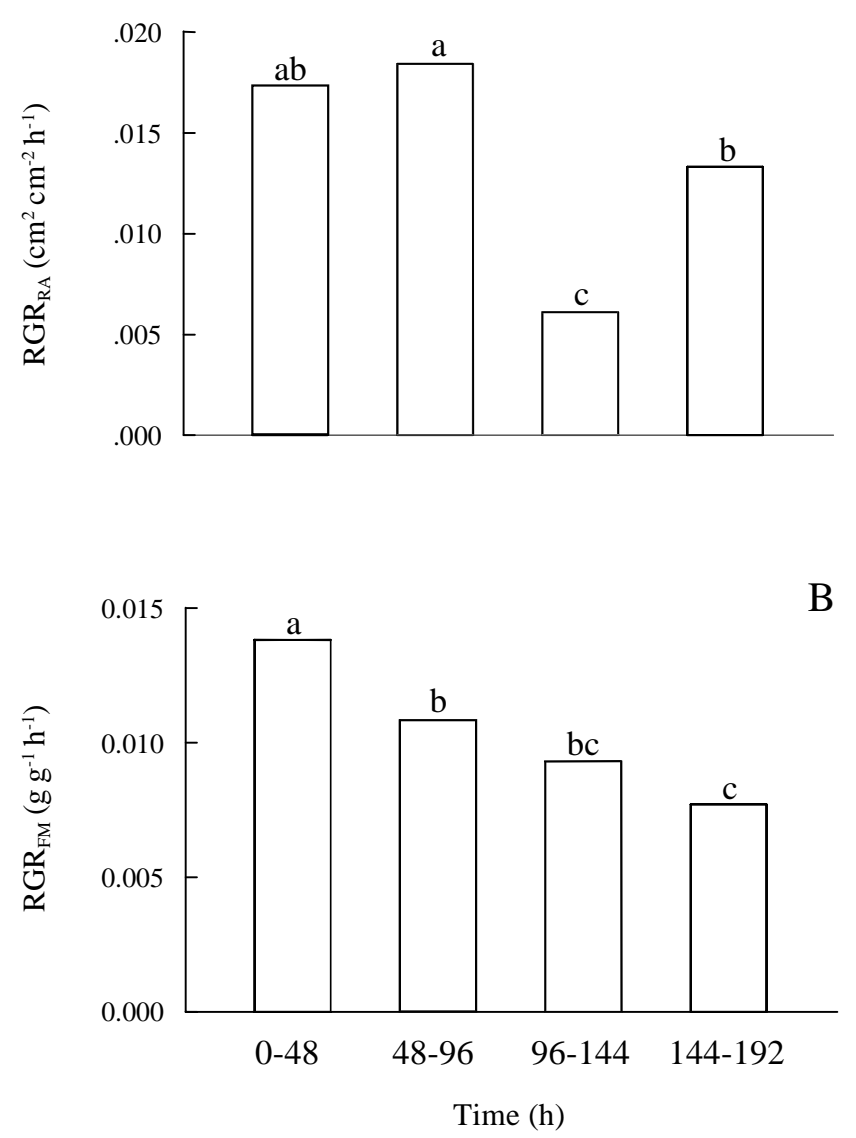

Figure 2. Relative Growth Rate (RGR) of rice seedling roots during four sequential growth cycles of 48 hours, in nutrient solution, expressed as (A): Root Area (RA); or (B) Fresh Root Mass (FM). Means followed by the same letter are not significantly different by Tukey's test $(P \leq 0.05)$.
Table 2. Measured $\mathrm{pH}$ variations and calculated total free proton $\left(\mathrm{U}_{\mathrm{H}}^{+}\right)$in nutrient solution, in each 48-hour cycle of rice seedling root growth.

\begin{tabular}{rccc}
\hline $\begin{array}{c}\text { Time } \\
(\mathrm{h})\end{array}$ & $\mathrm{pH}$ solution & $\Delta \mathrm{pH}^{(1)}$ & $\begin{array}{c}\mathrm{U}_{\mathrm{H}}{ }^{+} \\
\left(\mu \mathrm{mol} \mathrm{pot}^{-1}\right)\end{array}$ \\
\hline 0 & $5.30 \pm 0.02 \mathrm{a}^{(2)}$ & - & 17.54 \\
48 & $4.87 \pm 0.04 \mathrm{~b}$ & -0.43 & 47.21 \\
96 & $4.86 \pm 0.09 \mathrm{~b}$ & -0.44 & 48.54 \\
144 & $4.46 \pm 0.06 \mathrm{c}$ & -0.84 & 120.80 \\
192 & $4.29 \pm 0.01 \mathrm{~d}$ & -1.01 & 182.00 \\
\hline
\end{tabular}

${ }^{(1)}$ Difference between the measured $\mathrm{pH}$ at a given time period and $\mathrm{pH}$ at time $0 .{ }^{(2)}$ Statistics as in Table 1.

high temperatures and radiation levels prevalent in the initial period (Fig. 1) probably limited $\mathrm{U}_{\mathrm{H}}{ }^{+}$in the second period (48-96 h). In spite of this fact, the relationship between $\mathrm{U}_{\mathrm{H}}{ }^{+}$and RA or FM showed a fair linearity (Fig. 3).

$\mathrm{U}_{\mathrm{H}}^{+}$was better correlated to FM (Fig. 3A) than to RA (Fig. 3B). Using the values of the respective slopes $\left(279.43 \mu \mathrm{mol} \mathrm{H} \mathrm{g}_{\mathrm{FM}}^{-1}\right.$ or $\left.1.44 \mu \mathrm{mol} \mathrm{H} \mathrm{H}^{+} \mathrm{cm}_{\mathrm{RA}}^{-2}\right)$ and of $\mathrm{RGR}_{\mathrm{FM}}$ or $\mathrm{RGR}_{\mathrm{RA}}$ (Fig. 2) in equation (II), it is possible to calculate values of $\mathrm{E}_{\mathrm{H}}{ }^{+}$for each of the growth periods. Tab. 3 shows that the values oscillated between 0.02-0.046 $\mu \mathrm{mol} \mathrm{H} \mathrm{H}^{+} \mathrm{cm}^{-2} \mathrm{~h}^{-1}$ or 2.8-6.0 $\mu \mathrm{mol}$ $\mathrm{H}^{+} \mathrm{g}_{\mathrm{FM}}^{-1} \mathrm{~h}^{-1}$, with minimum values in the 48-96 hour period. Batista et al. (2000), using a different approach, reported that in 25-day-old rice seedlings grown in a nutritive solution of the same composition and with an equal concentration of $\mathrm{N}_{-} \mathrm{NH}_{4}^{+}$used in the present study, mean root $\mathrm{H}^{+}$effluxes ranged from 5.19 to $13.0 \mathrm{\rho mol} \mathrm{cm}^{-2} \mathrm{~s}^{-1}$, after a growth period of $6 \mathrm{~h}$. These values are very similar to those shown in Tab. 3, where, in equivalent units, $\mathrm{E}_{\mathrm{H}}^{+}$values ranged from 5.58 to $12.69 \rho \mathrm{mol} \mathrm{cm} \mathrm{cm}^{-2} \mathrm{~s}^{-1}$. It is interesting to observe that the values found by Batista et al. (2000) are related to two upland rice genotypes that were not genetically improved, which is not the case in the present study. Scott Russell (1977) observed that in nutritive solution, monocot nutrient uptake could be more closely related to root volume (RV) than to root length or root area. In the same way, we can infer that a root $\mathrm{H}^{+}$efflux originating from an excess of cation over anion uptake can also be well determined when related to FM or directly to RV. Arruda et al. (1983) observed that $\mathrm{pH}$ variation in nutrient solution, induced by $\mathrm{NH}_{4}^{+}$uptake in Brachiaria decumbens roots, was related to RV but not to root DM. Another interesting interconnection comes when considering the great increase in seminal axis growth rate $\left(2.5 \mathrm{~cm} \mathrm{day}^{-1}\right)$, 
A and RA were significantly less at $\mathrm{pH} 4.0$ than at $\mathrm{pH}$

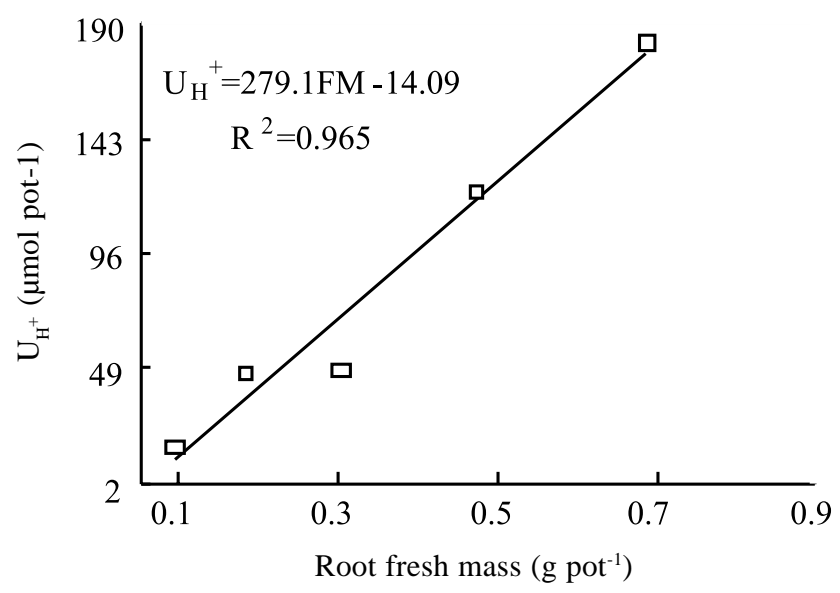

B

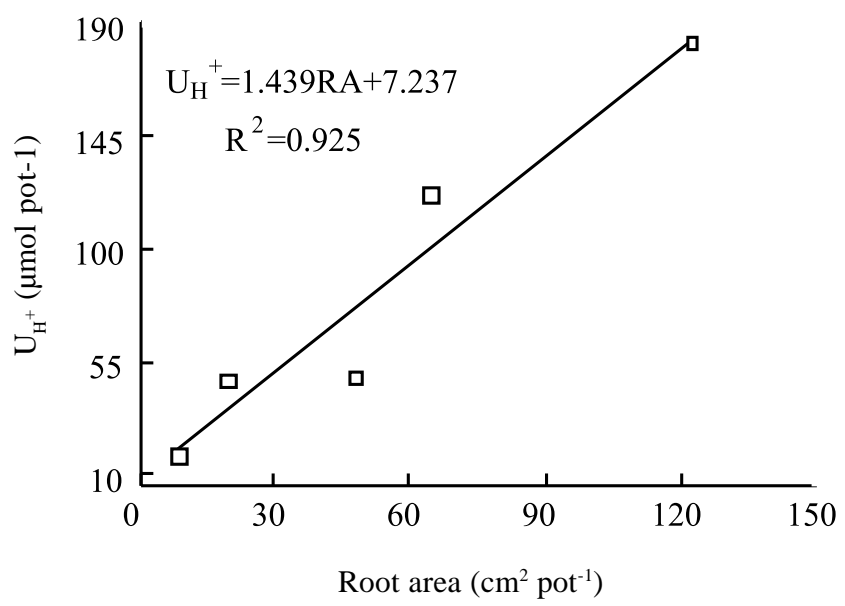

Figure 3. Regression lines of total free protons in solution $\left(\mathrm{U}_{\mathrm{H}}{ }^{+}\right)$ on (A) fresh root mass or (B) root area of rice seedlings. Values are means of three replicates.

Table 3. $\mathrm{H}^{+}$efflux rates $\left(\mathrm{E}_{\mathrm{H}}^{+}\right)$in each $48 \mathrm{~h}$ period of rice seedling root growth, expressed per unit root area (RA) or fresh mass (FM).

\begin{tabular}{|c|c|c|}
\hline \multirow{2}{*}{$\begin{array}{c}\text { Time } \\
\text { (h) }\end{array}$} & \multicolumn{2}{|c|}{$\mathrm{E}_{\mathrm{H}}^{+}$} \\
\hline & $\mu \mathrm{mol} \mathrm{H}^{+} \mathrm{cm}_{\mathrm{RA}}^{-2} \mathrm{~h}^{-1}$ & $\mu \mathrm{mol} \mathrm{H}^{+} \mathrm{g}_{\mathrm{FM}}^{-1} \mathrm{~h}^{-1}$ \\
\hline $0-48$ & 0.0457 & 4.58 \\
\hline 48-96 & 0.0201 & 2.84 \\
\hline $96-144$ & 0.0383 & 5.62 \\
\hline $144-192$ & 0.0379 & 5.96 \\
\hline
\end{tabular}

which occurred in the period corresponding to the extreme acidification of the solution, suggesting a stimulating effect of $\mathrm{pH}$ decrease on root elongation. Camargo et al. (1993) obtained a different result with a lowland rice cultivar (IRGA 409) grown in Hoagland solution in a controlled environment. In their study SRL 6.0 , showing that in rice, root growth responses to $\mathrm{H}^{+}$ stress are genotype-dependent. Precise measurements made with vibrating microelectrodes have detected an $\mathrm{H}^{+}$net influx region (or negative efflux) near the root tip (Ryan et al. 1992; Berbara et al. 1995). $\mathrm{E}_{\mathrm{H}}^{+}$positive values are associated with more distal regions (Berbara et al. 1995), where cations such as $\mathrm{NH}_{4}^{+}$and $\mathrm{K}^{+}$are apparently absorbed without restriction by the whole root system (Scott Russell 1977). However it should be mentioned that SRL values showed high variability within the same pot. Because of this fact, the root absorptive power cannot be well estimated by SRL measurement, the choice of this root trait is questionable as a basis for computing values of $\mathrm{E}_{\mathrm{H}}{ }^{+}$ representative of the whole root system.

From a more practical point of view, Glass et al. (1981) showed that $\mathrm{E}_{\mathrm{H}}^{+}$evaluations are useful as a screening method for the isolation of $\mathrm{K}^{+}$uptake efficient barley genotypes, suggesting that a similar approach could be applied to rice. Our work shows that, in young rice seedlings, estimates of root proton efflux can be expressed accurately in terms of fresh mass units, avoiding the determination of root surface area, a trait of larger variability. The calculation procedure of $\mathrm{E}_{\mathrm{H}}{ }^{+}$used in this work, based on sequential cycles of acidification, can be developed in greenhouse conditions since the fluctuations of light and temperature are regular enough to avoid abrupt effects on root growth rates. Under these conditions, and using growth periods of 48 hours, a linear relationship can be obtained among total protons in solution and the fresh root mass.

\section{Acknowledgements}

The authors thank Conselho Nacional de Desenvolvimento Científico e Tecnológico (CNPq), for financial support and David Bird (Université du Québec à Montréal), for English revision of the manuscript.

\section{References}

Arruda, M.L.R.A.; Fernandes, M.S. \& Rossiello, R.O.P. 1983. Alumínio e nitrogênio, nas variações do $\mathrm{pH}$ e capacidade de troca catiônica em Brachiaria decumbens. Pesquisa Agropecuária Brasileira 18: 1031-1036.

Baptista, J.A.; Fernandes, M.S. \& Souza, S.R. 2000. Morfologia do sistema radicular e cinética de absorção de nutrientes em duas variedades locais de arroz. Pesquisa Agropecuária Brasileira 35: 1325-1330. 
Berbara, R.L.L.; Morris, B.M.; Fonseca, H.M.A.C.B.; Reid, N.A.R.G. \& Daft, M. 1995. Electrical currents associated with arbuscular mycorrhizal interactions. New Phytologyst 129: 433-438.

Camargo, F.A.O.; Santos, G.A. \& Rossiello, R.O.P. 1993. Efeito dos ácidos acético e butírico sobre o crescimento de plântulas de arroz. Pesquisa Agropecuária Brasileira 28: 1011-1018.

Fernandes, M.S. \& Rossiello, R.O.P. 1995. Mineral nitrogen in plant physiology and plant nutrition. Critical Reviews in Plant Sciences 14: 111-148.

Fernandes, M.S.; Didonet, H.R. \& Rossiello, R.O.P. 1981. Respostas de quatro cultivares de arroz à aplicação de nitrogênio amoniacal com um inibidor de nitrificação. Pesquisa Agropecuária Brasileira 16: 303-307.

França, M.G.C.; Rossiello, R.O.P.; Zonta, E.; Araújo, A.P. \& Ramos, F.T. 1999. Desenvolvimento radicular e influxo de nitrogênio em duas cultivares de arroz. Pesquisa Agropecuária Brasileira 34: 1845-1853.

Furlani, A.M.C. \& Furlani, P.R. 1988. Composição e pH das soluções nutritivas para estudos fisiológicos e seleção de plantas em condições nutricionais adversas. Boletim Técnico 121 Campinas, Instituto Agronômico de Campinas.

Glass, A.D.M.; Siddiqi, M.Y. \& Giles, K.I. 1981. Correlation between potassium uptake and hydrogen efflux in barley varieties. A potential screening method for the isolation of nutrient efficient lines. Plant Physiology 68: 457-459.

Hsiao, T.C.; Acevedo, E.; Fereres, E. \& Henderson, D.W. 1976. Stress metabolism. Water stress, growth and osmotic adjustment. Series B; Biological Sciences. Philosophical Transactions of the Royal Society of London 273: 479-500.

Lew, R.R. 1996. Pressure regulation of the electrical properties of growing Arabidopsis thaliana L. root hairs. Plant Physiology 112: 1089-1100.

Lew, R.R. 1998. Immediate and steady state extracellular ionic fluxes of growing Arabidopsis thaliana root hairs under hyperosmotic and hypoosmotic conditions. Physiologia Plantarum 104: 397-404.

Luisi, M.V.V.; Rossiello, R.O.P. \& Fernandes, M.S. 1983. Acidificação do rizocilindro de milho em resposta à absorção de nutrientes e sua relação com o crescimento radicular. Revista Brasileira de Ciência do Solo 7: 69-74.

Mantelin, S. \& Touraine, B. 2004. Plant growth-promoting bacteria and nitrate availability: impact of development and nitrate uptake. Journal of Experimental Botany 55 : 27-34.
Michelet, B. \& Boutry, M. 1995. The plasma-membrane $\mathrm{H}^{+}-$ ATPase - A highly regulated enzyme with multiple physiological functions. Plant Physiology 108: 1-6.

Miller, A.L.; Raven, J.A.; Sprent, J.I. \& Weisenseel, M.H. 1986. Endogenous ion current traverse growing roots and root hairs of Trifolium repens. Plant Cell Environment 9: 79-83.

Plassard, C.; Meslem, M.; Souche, G. \& Jaillard, B. 1999. Localization and quantification of net fluxes of $\mathrm{H}^{+}$along maize roots by combined use of $\mathrm{pH}$-indicator dye video densitometry and $\mathrm{H}^{+}$-selective microelectrodes. Plant and Soil 211: 29-39.

Raven, J.A. \& Smith F.A. 1976. Nitrogen assimilation and transport in vascular land plants in relation to intracellular $\mathrm{pH}$ regulation. New Phytologist 76: 415-431.

Rossiello, R.O.P.; Araujo, A.P.; Manzato, C.V. \& Fernandes, M.S. 1995. Comparação dos métodos fotoelétrico e da interseção na determinação de área, comprimento e raio médio radicular. Pesquisa Agropecuária Brasileira 30: 633-638.

Ryan, P.R.; Shaff, J.H. \& Kochian, L.V. 1992. Aluminium toxicity in roots. Correlation among ionic currents, ion fluxes, and root elongation in aluminium-sensitive and aluminium-tolerant wheat cultivars. Plant Physiology 99: 1193-1200.

Scott Russell, R. 1977. Plant root systems: their function and interaction with the soil. London, McGraw-Hill Book Company.

Serrano, R. 1989. Structure and function of plasma membrane ATPase. Annual Review of Plant Physiology and Plant Molecular Biology 40: 61-94.

Shabala, S. \& Newman, I. 2000. Salinity effects on the activity of plasma membrane $\mathrm{H}^{+}$and $\mathrm{Ca}^{2+}$ transporters in bean leaf mesophyll: masking role of the cell wall. Annals of Botany 85: 681-686.

Silva, F.L.I.M.; Rossiello, R.O.P. \& Fernandes, M.S. 1987. Nutrição amoniacal com e sem N-Serve: Efeitos sobre o crescimento radicular do milho. Pesquisa Agropecuária Brasileira 22: 567-574.

Smart, D.R. \& Bloom, A.J. 1998. Investigations of ion absorption during $\mathrm{NH}_{4}^{+}$exposure I. Relationship between $\mathrm{H}^{+}$efflux and $\mathrm{NO}_{3}^{-}$absorption. Journal of Experimental Botany 49: 95-100.

Stiles, K.A.; Mcclintick, A. \& Van Volkenburgh, E. 2003. A developmental gradient in the mechanism of $\mathrm{K}^{+}$uptake during light-stimulated leaf growth in Nicotiana tabacum L. Planta 217: 587-596.

Systat Version 8.0 Copyright (C SPSS Inc. 1998. All rights reserved. Standard Version. 